\title{
Psychopathology in Premenstrual Syndrome
}

\author{
Halil Özcan¹, Burak Subașı²
}

ÖZET:

Premenstrual sendrom'da psikopatoloji

\begin{abstract}
Amaç: Premenstruel sendromda (PMS) belirtileri daha kapsamlı tarayarak daha öncesinde yeterince vurgulanmamış belirtilerin PMS'da önemsenecek düzeyde sık görüldüg̃üne dair bulgular toplamak.

Yöntem: Çalıșmaya Ankara Zekai Tahir Burak Kadın Sag̃lıg̃ı Eg̃itim ve Araștırma Hastanesi Gençlik Ünitesi'ne bașvuran hastalar arasından rastgele seçilen 127 kişi alınmıştır. Katılımcılara önce bir sosyodemografik veri formu verilmiş, ardından premenstrual deg̃erlendirme formu (PAF) ve belirti tarama listesini (SCL-90-R) doldurmaları istenmiștir. PAF'dan 2'nin üzerinde ortalama puan almış olmak PMS olasılı̃̃ını düşündürmektedir. SCL-90-R'den alınan puanın artması olası psikopatoloji varlıg̃ını, alt ölçeklerden alınan puanın artması 0 alandaki olası psikopatoloji varlıg̃ını düşündürmektedir.
\end{abstract}

Bulgular: Çalışmamızda PMS görülme oranı \%16 olarak bulundu. Çalışmamızda 21 katılımcı PAF'dan ortalama 2'den yüksek puan almıştır. PMS puanları ile ek skala puanları dışında SCL-90-R'nin bütün alt maddeleri ve genel belirti ortalaması puanları arasında istatistiksel olarak anlamlı ilişki saptanmıștır.

Sonuç: Biz bu çalışmada SCL-90-R kullanarak PMS'da sadece depresif, anksiyete ya da öfke belirtilerinin görülmediğini, görülen ruhsal belirtilerin birçok alanda oldug̃unu bulduk. Bu bulguların ileride PMS belirtileri yaşayan kadınların ruhsal durumlarının anlaşılabilmesi, çalışıımayan dig̃er alanlarla da ilgili bir fikir vereceg̃ini düşünmekteyiz.

Anahtar sözcükler: psikopatoloji, premenstrual sendrom, SCL-90-R

Journal of Mood Disorders 2013;3(4):146-9

\section{ABSTRACT: \\ Psychopathology in premenstrual syndrome}

objective: Collecting data by scanning symptoms comprehensively, especially those that were frequent and should be noted but had not been enough emphasized before with regard to Premenstrual Syndrome (PMS).

Methods: The study includes 127 individual who were randomly selected from among those admitted to Zekai Tahir Burak Women's Health Education and Research Hospital Youth Unit in Ankara. First, a demographic data form was given to participants. Then, they were asked to complete a premenstrual assessment form (PAF) and symptom checklist (SCL-90-R). Having an average score above 2 points is an indicator of PMS in PAF. SCL-90-R general average score increase means to have probable general psychopathology, increase in any subscales of SCL-90-R means to have probable psychopathology on that field.

Results: In this study, premenstrual syndrome (PMS) frequency was found to be $16 \%$. Twenty-one participants received more than 2 points as an average on the PAF. Relationships were found between PMS scores and all items of the SCL-90-R, including general symptom averages, except for the additional scale.

Conclusion: In this study, by using the SCL-90-R, we found that in cases of PMS not only depression, anxiety, and anger but also other mental symptoms occur. We think that these findings will help us to understand the psychological status of women with PMS symptoms and give us ideas regarding fields that have not been studied before.

Key words: psychopathology, premenstrual syndrome, SCL-90-R

Journal of Mood Disorders 2013;3(4):146-9
'Psychiatrist Assistant Professor, Atatürk University Medical School Department of Psychiatry, Erzurum-Turkey ${ }^{2}$ Psychiatrist Specialist, Elazig̃ Education and Research Hospital, Elazı̃g-Turkey

Yazıșma Adresi / Address reprint requests to: Halil Özcan, Ataturk University Medical School Department of Psychiatry, Erzurum-Türkiye

Elektronik posta adresi / E-mail address: halilozcan23@yahoo.com

Telefon / Phone: +90-442-231-7362

Faks / Fax: +90-442-231-5000

Kabul tarihi / Date of acceptance: 14 Mayıs 2013 / May 14, 2013

Bag̃ıntı beyanı:

H.O., B.S.: Yazarlar bu makale ile ilgili olarak herhangi bir çıar çatıșması bildirmemișlerdir.

Decloration of interest:

H.O.., B.S.: The authors reported no conflict of interest related to this article.

\section{INTRODUCTION}

Menstruation is a physiological process that occurs over 30-35 years of a woman's life. Some women experience somatic, emotional, and behavioral symptoms during the premenstrual period (1). Premenstruel syndrome (PMS) is defined as a state with clinically significant emotional, physical and behavioral symptoms that begins during the last week of the menstrual cycle and ends a few days after the initiation of the follicular phase $(1,2)$. The only material that may be useful in the diagnosis of PMS is a menstrual calendar. At least 3 
months of observations should be recorded. In the diagnosis of PMS, three steps are important: having symptoms related to the menstrual cycle; these symptoms having a characteristic, repetitive nature; and their severely effecting the woman's life, such as by affecting social relations, activities, etc (3). According to the National Institute of Mental Health (NIMH), to diagnose PMS, there should be a $30 \%$ difference between the severity of the symptoms during the 5 days before menstruation and the severity of those during the 5 days after menstruation (3).

The most common emotional problems during PMS are anxiety, hostility, and depression. As a reflection of the severity of depression, approximately $70 \%$ of women with PMS might have recurrent suicidal ideation, and $20 \%$ attempt to suicide $(1,4)$. In terms of the etiology of PMS, it is believed that physiological, biological, psychological, and sociological factors are important (5).

In this research project, we aimed to explore the frequency of PMS symptoms and those psychiatric symptoms that are probably related to PMS.

\section{METHOD}

The sample of this study included 127 randomly selected individuals between the ages of 18 and 24 who were chosen from among those admitted to Ankara Zekai Tahir Burak Women's Health Education and Research Hospital Youth Center between January and March of 2012. Individuals older than 24 ages are not accepted by the youth center. Participants having chronic medical illnesses, psychiatric diagnoses, or prior or current treatments were excluded. Participants were asked to complete a demographic data form and then a premenstrual assessment form and symptom check list revised (SCL-90-R).

Premenstrual Assessment Form (PAF): PAF is a selfreport scale that was developed to measure the symptoms that occur during the premenstrual period. It was created in 1982 by Halbreich (6). The scale consists of 95 items that are scored between 0 and 4 . If the average score is above 2, this is an indicator of premenstrual syndrome. The translation into Turkish, as well as the confirmation of the reliability and validity of the scale, was performed by Dereboy and colleagues in 1994 (7).
Symptom Check List-Revised (SCL-90-R): SCL-90-R is a 5 -point likert scale questionnaire that includes 90 selfreport items used to scan for psychiatric symptoms. It was developed by Derogatis and colleagues in 1977 (8-10). The items of the scale are scored between 0 and 4 . The scale consists of nine subscales that scan for somatization, obsessive-compulsive disorder, interpersonal sensitivity, depression, anxiety, hostility, phobic anxiety, paranoid ideation, and psychoticism, as well as an additional subscale. The scale was adapted for young Turkish people by Sahin and colleagues in 1994 (11).

Increases in the overall average scores indicate an increasing level of distress due to the existence of psychiatric symptoms. Subscale scores are used to scan for the psychiatric symptoms mentioned above. Having an average score above 1.5 points in general average means to have general probable psychopathology and having an average score above 1.5 points in any subscales of SCL-90-R means to have a probable psychopathology on that field (12).

\section{Statistical Analysis}

Data were analyzed using the Statistical Package for Social Sciences (SPSS) version 16.0. Demographic data analyses were subjected to the mean procedure for descriptive statistics. Pearson correlation analyses were used to determine the relationships between the PMS symptoms and the SCL-90-R subscales. The statistical significance level was taken to be $\mathrm{p}<0.05$.

\section{RESULTS}

The mean age of the participants was found to be $20.4 \pm 2.3$. The sociodemographic data of the participants are given in Table 1.

Table 1: Sociodemographic data of the participants

\begin{tabular}{ll} 
Education level & (n) \\
\hline Elementary school & 18 \\
High school & 62 \\
College (continuing education) & 35 \\
College & 12 \\
Place of residence & \\
Alone & 10 \\
In dorms & 14 \\
With families & 103
\end{tabular}


Table 2: SCL-90-R subscale scores and correlations with PAF scores

\begin{tabular}{|c|c|c|c|}
\hline SCL-90-R subscales & Mean \pm SD & $\begin{array}{l}\text { SCL-90-R } \\
\text { r values }\end{array}$ & $\begin{array}{l}\text { AF total score correlations } \\
\text { p values }\end{array}$ \\
\hline Somatization & $1.36 \pm 0.94$ & $0.784^{*: *}$ & $p<0.001$ \\
\hline Obsessive compulsive & $1.3 \pm 0.96$ & $0.767^{*}$ & $p<0.001$ \\
\hline Interpersonal sensitivity & $1.30 \pm 1.07$ & $0.712^{\text {t* }}$ & $p<0.001$ \\
\hline Depression & $1.25 \pm 0.98$ & 0.784 & $p<0.001$ \\
\hline Anxiety & $1.07 \pm 0.95$ & 0.756 & $p<0.001$ \\
\hline Hostility & $1.2 \pm 0.98$ & $0.726^{* *}$ & $p<0.001$ \\
\hline Phobic anxiety & $0.81 \pm 0.87$ & $0.676^{* *}$ & $p<0.001$ \\
\hline Paranoid ideation & $1.1 \pm 1.04$ & $0.680 \%$ & $p<0.001$ \\
\hline Psychoticism & $0.8 \pm 0.84$ & $0.691^{*:}$ & $p<0.001$ \\
\hline Additional scales & $1.08 \pm 0.88$ & $0.674^{* t}$ & $p<0.001$ \\
\hline General symptoms average & $1.15 \pm 0.85$ & 0.820 & $p<0.001$ \\
\hline
\end{tabular}

SCL-90-R: Symptom Checklist-90-Revised, PAF: Premenstrual Assessment Form, "*: : statistically significancy level p<0.001, SD: Standart deviation

Twenty-six participants in the study had been admitted to the hospital because of menstruation problems (painful menstruation, irregular menstruation, excessive bleeding, etc). In this study, 21 participants scored higher than 2 points in average on the PAF. Premenstrual syndrome scores were found to be strongly positively correlated with all nine of the SCL-90-R subscales $(\mathrm{p}<0.001)$ in the 21 participants scoring higher than 2 points on the PAF. Also, in general, a positive correlation was found between the symptom average on the SCL-90-R, SCL-90-R subscales and the score on the PAF. The scores on the SCL-90-R subscales and correlations between SCL-90-R subscales and PAF scores are shown in Table 2.

\section{DISCUSSION}

Despite the small sample size of our study, which included 127 patients in total, we can say that we found PMS rate to be $16 \%$. The most frequent symptoms reported in the DSM-IV were anxiety, tension, rapid emotional changes, crying, anger, irritability, drowsiness, decreased energy, and headache. Previously, in many studies, a relationship between psychopathology and PMS has been shown. A lifetime history of anxiety or mood disorders was reported in over half of the women who presented PMS. The rate of depression among patients with PMS is greater than that in healthy women. In a prior study, it was found that $6.1 \%$ of women with PMS, had very high rates of psychiatric disorders, especially depression (13). In this mentioned study, the severity of PMS symptoms was also found to be positively correlated with previous or current psychiatric illnesses. In another research, subjects having PMS were shown to have higher levels of pre-existing psychiatric disorders, postpartum psychiatric illness, and current psychiatric illnesses, as well as having first-degree relatives with a history of psychiatric illness at higher rates than subjects without PMS (14). The most common and severe PMS symptoms were feeling irritable and restlessness. Other frequent and severe symptoms include feeling distressed, abdominal distension, discomfort or pain, lack of energy, occasional abdominal pain, cramps in the legs, and being more sensitive to changes in temperature (14).

The effects of estrogen and progesterone have been demonstrated on neurotransmitters such as serotonin, opioids, catecholamines, and GABA. Lower levels of serotonin, B-endorphin, and GABA during the luteal phase provoke negative mood symptoms and adverse emotional reactions $(15,16)$. Various biological and psychological factors have been proposed as causing PMS, including the absence of progesterone, abnormal serotonin function, the altered endorphin modulation of gonadotropin secretion, GABA receptor sensitivity, lack of exercise, and poor dietary habits (17-21). Rather than a hormonal imbalance, the cyclical course of PMS has been suggested to be the result of a complex chain of psychoneuroendocrine events that is triggered by normal ovulation (22).

In addition, by using the premenstrual syndrome symptom checklist, in this study, we found that women with PMS may not be experiencing only depression, anxiety, or anger. Rather, they may have psychiatric symptoms that 
cover a wide range. One of the limitation of this study is the small sample size, and another is that the SCL-90-R is a scale that is used for screening, not for diagnosis.

We believe that our findings may inspire others to explore the psychiatric conditions of women with PMS.

\section{References:}

1. Dilbaz N. Premenstruel sendrom. Türk Psikiyatri Dergisi. 1992;1:42-7.

2. Platin N. Premenstruel sendrom. Ege Üniversitesi Hemşirelik Yüksekokulu Dergisi. 1989;5:31-4.

3. Speroff L, Glass RH, Kase NG. Clinical Gynecologic Endocrinology and Infertility. 1994;2:515-30.

4. Kocabaşoğlu N, Hacıosman F, Karaali F, Kocabaşoğlu C Premenstruel gerilim sendromunda depresyon, anksiyete. Yeni Sempozyum. 1994;1:40-2.

5. Paulson MJ. Psychological concomitants of premenstrual tension Am J Obstet Gynecol 1961;81:733-8.

6. Halbreich U, Endicott J, Schacht S, Nee J. The diversity of premenstrual changes as reflected in the Premenstrual Assessment Form. Pathophysiology of premenstrual syndrome and premenstrual dysphoric disorder. Acta Psychiatrica Scandinavica. 1982;65:46-65.

7. Dereboy Ç, Dereboy İF, Yiğitol F. Premenstruel değerlendirme formunun psikometrik verileri küme analitik bir çalışma. Türk Psikiyatri Dergisi.1994;2:83-90.

8. Derogatis LR. SCL-90-R, administration, scoring and procedures manual-I for the R(evised) version. Baltimore: John Hopkins University School of Medicine 1977.

9. Derogatis LR, Cleary PA. Confirmation of the dimensional structure of the SCL-90: A study in construct validation. Journal of Clinical Psychology. 1977;33:981-9.

10. Derogatis LR, Cleary PA. Factorial invariance across gender for the primary symptom dimensions of the SCL-90. British Journal of Social and Clinical Psychology. 1977;16:347-56.

11. Şahin NH, Durak A. Kısa Semptom Envanteri: Türk Gençleri için Uyarlanması" Türk Psikoloji Dergisi. 1994;9:44-56.

12. Duran Ş. Psikiyatri Polikliniğine Başvuran Hastalarda Erişkin Dikkat Eksikliği- Hiperaktivite Bozukluğu Sıklığı Ve Eștanı Durumları Yayınlanmamış Uzmanlık Tezi İstanbul 2006.

\section{Acknowledgement}

There is no conflict of interest in this study. Ankara Zekai Tahir Burak Women Health Education and Research Hospital Ethics Committee has approved the study.

13. Gehlert S, Hartlage SA. Design for studying the DSM-IV. Research criteria of premenstrual dysphoric disorder. Psychosom Obstet Gynaecol. 1997;1:36-44.

14. Harrison WM, Endicott J, Nee J. Characteristics of women seeking treatment for premenstrual syndrome. Psychosomatics. 1989;30:405-10.

15. Halbreich U. The etiology, biology, and evolving pathology of premenstrual syndromes. Psychoneuroendocrinology. 2003;28:5599.

16. Fava M, Pedrazzi F, Guaraldi G P, Genazzani AR, Facchinetti F. Comorbid anxiety and depression among patients with late luteal phase dysphoric disorder. J Anxiety Disord. 1992;6:325-35.

17. Mortola JF. Premenstrual syndrome pathophysiologic considerations. N Engl J Med. 1998;338:256-7.

18. Steiner M, Pearlstein T. Premenstrual dysphoria and the serotonin system: Pathophysiology and treatment. J Clin Psychiatry. 2000;61:17-21.

19. Freeman EW. Luteal phase administration of agents for the treatment of premenstrual dysphoric disorder. CNS Drugs. 2004; 18:453.

20. Schmidt PJ, Neiman LK, Grover GN, Muller KL, Merriam GR, Rubinow DR. Lack of effect of induced menses on symptoms in women with premenstrual syndrome. N Engl J Med.1991;324:11749

21. Schmidt PJ, Nieman LK, Danaceau MA, Adams LF, Rubinow DR. Differential behavioral effects of gonadal steroids in women with and in those without premenstrual syndrome. N Engl J Med. 1998;338:209-16.

22. Steiner M, Dunn EJ. The psychobiology of female-specific mood disorders. Infertil Reprod Med Clin North Am. 1996;7:297-313. 